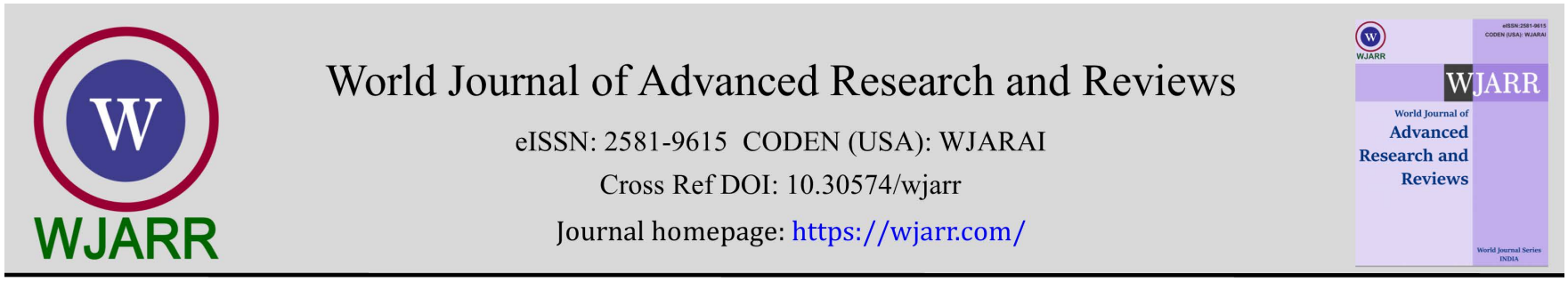

(RESEARCH ARTiCle)

Check for updates

\title{
The relationship between socio-economic statuses to nutritional status of first grade students in private primary school in north Surabaya
}

\author{
M Gita Jayanata $1{ }^{*}$, Mira Irmawati ${ }^{2}$, Lilik Djuari ${ }^{3}$ and Sri Umijati ${ }^{3}$ \\ ${ }^{1}$ Medical Program, Faculty of Medicine, Universitas Airlangga, Surabaya, Indonesia. \\ 2 Department of Pediatric, Faculty of Medicine, Universitas Airlangga, Surabaya, Indonesia. \\ ${ }^{3}$ Department of Public Health and Preventive Medicine, Faculty of Medicine, Universitas Airlangga, Surabaya, Indonesia.
}

World Journal of Advanced Research and Reviews, 2022, 13(01), 473-480

Publication history: Received on 02 December 2021; revised on 10 January 2022; accepted on 12 January 2022

Article DOI: https://doi.org/10.30574/wjarr.2022.13.1.0023

\begin{abstract}
Introduction: Low socio-economic status is one of the major causes of malnutrition. However, several studies of students at private elementary schools, which are often considered to have a good socio-economic status, show that malnutrition (both under and overnutrition) is quite high as measured based on BAZ (BMI-for-aged-Z-score) indicator.
\end{abstract}

Method: This cross-sectional design study began in March 2020 and finish in November 2021 by collecting data from the Google form questionnaire. As many as 86 students in first-grade students who were in two private elementary schools, SD Al-Irsyad and SD Al-Muttaqien in North Surabaya became the sample (total sampling). The independent variable was the student's socio-economic and the dependent variable was the student's nutritional status based on the BAZ indicators. The wilcoxon test was used to determine the relationship between socio-economic status and nutritional status of students.

Results: The most common student characteristics come from aged 7 years old (70\%), boy (64\%), and SD Al-Irsyad $(53,5 \%)$. The highest nutritonal status are normal (57.0\%), followed by overnutrition (12,8\%-overweight and $20.9 \%$ obese) and undernutrition (9,3\%-thin). Based on family socio-economic status, most of them have upper education level (62.8\%-fathers and 66.3\%-mothers), working status (97.7\%-fathers and 52.3\%-mothers), and upper family expenditure level (60.5\%). However, there is no relationship between socio-economic status and nutritional status of students $(\mathrm{p}>0.05)$.

Conclusion: The results of this study prove that there is no relationship between socio-economic status and nutritional status of students because the data from the two variables are less varied. More varied data are needed in further research.

Keywords: Nutritional Status; Socio Economic Status; Elementary Students; Private Elementary Students

\section{Introduction}

Low socio-economic status is one of the major causes of malnutrition [1]. However, study on private elementary school students, who are often considered to have good socio-economic status, shows that the malnutrition percentage based on BAZ examination is $33.7 \%$, either under or overnutrition [2].

\footnotetext{
${ }^{*}$ Corresponding author: M Gita Jayanata

Medical Program, Faculty of Medicine, Universitas Airlangga, Surabaya, Indonesia.

Copyright $(2022$ Author(s) retain the copyright of this article. This article is published under the terms of the Creative Commons Attribution Liscense 4.0.
} 
The distribution of malnutrition in private elementary schools shows different results. Study in Kupang City showed a higher percentage of under nutrition status at 19.2\% [2]. On the other hand, study in Jakarta on the same type of population showed a higher percentage of over nutrition status with $47.75 \%$ [3].

Malnutrition is reported to reduce scores on subjects in class and decrease school attendance in students [4, 5]. On the overnutrition children, the relationship with academic performance can be seen with a decrease in body resistance such as cardiorespiratory function, muscle strength, and agility [6].

Socio-economic status determines nutritional status through four factors namely parenting patterns, availability and accessibility of food, access to health services, and environmental sanitation and hygiene. All of these factors can affect children's health and shape their nutritional status. The fulfillment of socio-economic status is determined by three main factors, namely the parents' education level, the parents' occupation status, and family expenditure level [7]. Family expenditures are choosen because it's more representative than family income in shaping socioeconomi status [8].

Education is one of the important factors to get occupation. As higher as parents' education level, they are more feasible to get better work. Conversely, as lower as parents' education level, they are more difficult to get proper job because it requires certain skills or specialties that are obtained at a higher level of education [9].

Parents' employment status also determine the family life. As better as parents job (professionals, leadership staff, and managers), they are more feasible to get better income [10]. Education and occupation also determine income and then determine family expenses, including meeting nutritional needs [11].

Based on this theory and findings, it is important to understand the nutritional status of elementary school children from a socio-economic perspective to anticipate academic performance's problems. This research is expected to provide information to increase knowledge or be considered in designing nutrition policies.

\section{Material and methods}

The study began in March 2020 and finish in November 2021. This study is an analytic observational approach with a cross-sectional design research. The population is first-grade students who are in two private elementary schools, SD Al-Irsyad and SD Al Muttaqien in North Surabaya with a total of 168 students. Sample collection uses total sampling. Inclussion criteria is the first-grade students and exclusion criteria such as students who don't receive a scholarship or live with their parents.

The independent variable is the socio-economic such as the parents' education (upper namely collage graduate, middle namely junior and senior high school graduate, and lower namely elementary school graduate or below), parents' employment status (working or not), and family expenditure levels (upper namely upper than Rp $4,200,000$,- or lower namely below than $\mathrm{Rp} \mathrm{4,200,000,-).} \mathrm{Meanwhile,} \mathrm{the} \mathrm{dependent} \mathrm{variable} \mathrm{is} \mathrm{the} \mathrm{anthropometric}$ result examination based on BAZ (BMI-for-aged-Z-score) indicator obtained by Z score of BMI (Body Mass Indexs for Age). The results were divided into three groups, namely undernutrition status (thinnes <-2SD), normal nutrition (2SD to 1SD), and overnutrition (overweight $>1$ SD to 2 SD and obesity $>2$ SD). Data was collected from a Google form questionnaire, both socio-economic and nutritional status data and processed through the IBM SPSS version 26 Test and Microsoft Excel. This study uses the wilcoxon test because the data doesn't normally distributed.

\section{Results}

\subsection{Demographic Characteristics}

A total of 86 students were enrolled in this study with the most common student characteristics come from aged 7 years old (70\%), boy (64\%), and SD Al-Irsyad (53,5\%). While the most common parents' age, both father and mother is 31 to 40 years old. 
Table 1 Characteristics of Respondents by Age, Gender, and School

\begin{tabular}{|c|c|c|}
\hline Characteristic & Size (n) & Percentage $(\%)$ \\
\hline \multicolumn{3}{|l|}{ Students Age } \\
\hline 6 & 35 & $40.7 \%$ \\
\hline 7 & 48 & $55.8 \%$ \\
\hline 8 & 3 & $3.5 \%$ \\
\hline \multicolumn{3}{|l|}{ Father Age } \\
\hline $21-30$ & 2 & $2.3 \%$ \\
\hline $31-40$ & 59 & $68.6 \%$ \\
\hline $41-50$ & 18 & $20.9 \%$ \\
\hline $51-60$ & 7 & $8.1 \%$ \\
\hline \multicolumn{3}{|l|}{ Mother Age } \\
\hline $21-30$ & 8 & $9.3 \%$ \\
\hline $31-40$ & 63 & $73.3 \%$ \\
\hline $41-50$ & 15 & $17.4 \%$ \\
\hline \multicolumn{3}{|l|}{ Gender } \\
\hline Boys & 55 & $64.0 \%$ \\
\hline Girls & 31 & $36.0 \%$ \\
\hline \multicolumn{3}{|l|}{ School } \\
\hline SD Al-Irsyad & 46 & $53.5 \%$ \\
\hline SD Al Muttaqien & 40 & $46.5 \%$ \\
\hline Total & 86 & $100.0 \%$ \\
\hline
\end{tabular}

Table 2 Characteristics of Family Socio-Economi Status

\begin{tabular}{|l|l|c|c|}
\hline \multirow{2}{|l|}{ Characteristic } & N (Total=86) & Percentage (\%) \\
\hline \multirow{2}{*}{ Parents Education Level } \\
\hline \multirow{2}{*}{ Father } & Upper & 54 & $62.8 \%$ \\
\cline { 2 - 4 } & Middle & 29 & $33.7 \%$ \\
\cline { 2 - 4 } & Lower & 3 & $3.5 \%$ \\
\hline \multirow{2}{*}{ Mother } & Upper & 57 & $66.3 \%$ \\
\cline { 2 - 4 } & Middle & 29 & $33.7 \%$ \\
\hline \multirow{2}{*}{ Parents Employment Status } & \\
\hline \multirow{2}{*}{ Father } & Working & 84 & $97.7 \%$ \\
\cline { 2 - 4 } & Not & 2 & $2.3 \%$ \\
\hline \multirow{2}{*}{ Mother } & Working & 45 & $52.3 \%$ \\
\cline { 2 - 5 } & Not & 41 & $47.7 \%$ \\
\hline \multirow{2}{*}{ Family Expenditure Level (based of Surabaya's Minimum Wage) } \\
\hline Upper & 52 & $60.5 \%$ \\
\hline Lower & 34 & $29.5 \%$ \\
\hline \multicolumn{2}{|l|}{ Total } & 86 & $100.0 \%$ \\
\hline
\end{tabular}

In table 2, the upper education level is higher than other education levels, both father and mother. Based on parents' employment status, the working status of parents is higher than those who are not. However, the percentage of working 
mothers is almost the same as that of non-working mothers (52.3\% vs. $47.7 \%)$. Based on the family expenditure level, the upper family expenditure level is higher than below. In table 3 , normal nutritional status is higher than malnutrition status $(57,0 \%)$. While the overnutrition, both overweight and obessity is higher than undernutrition $(33,7 \%)$.

Table 3 Characteristics of Nutritional Status Based on BMI-for-Age-Z-Score (BAZ)

\begin{tabular}{|l|c|c|}
\hline Characteristic & Size (n) & Percentage (\%) \\
\hline Thinnes & 8 & $9.3 \%$ \\
\hline Normal & 49 & $57.0 \%$ \\
\hline Overweight & 11 & $12.8 \%$ \\
\hline Obessity & 18 & $20.9 \%$ \\
\hline Total & 86 & $100.0 \%$ \\
\hline
\end{tabular}

Normal nutrition status is higher than malnutrition status in parents with upper education level than other. However, malnutrition, both under and overnutrition is higher in upper education level (table 4).

Table 4 the Relationship of Socio-Economi Status to Nutritional Status

\begin{tabular}{|c|c|c|c|c|c|c|c|c|c|}
\hline \multirow{3}{*}{ Characteristics } & \multicolumn{8}{|c|}{ BAZ } & \multirow{3}{*}{ P-Value } \\
\hline & \multicolumn{2}{|c|}{ Thinnes } & \multicolumn{2}{|c|}{ Normal } & \multicolumn{2}{|c|}{ Overweight } & \multicolumn{2}{|c|}{ Obessity } & \\
\hline & $\mathbf{n}$ & $\%$ & $\mathbf{n}$ & $\%$ & $\mathbf{n}$ & $\%$ & $\mathbf{n}$ & $\%$ & \\
\hline \multicolumn{10}{|c|}{ Father Education Level } \\
\hline Upper & 5 & 62.5 & 31 & 63.3 & 6 & 54.5 & 12 & 66.7 & \multirow{3}{*}{0.943} \\
\hline Middle & 3 & 37.5 & 17 & 34.7 & 4 & 36.4 & 5 & 27.8 & \\
\hline Lower & 0 & 0.0 & 1 & 33.3 & 1 & 33.3 & 1 & 33.3 & \\
\hline \multicolumn{10}{|c|}{ Mother Education Level } \\
\hline Upper & 7 & 87.5 & 32 & 65.3 & 7 & 63.6 & 11 & 61.1 & \multirow{2}{*}{0.064} \\
\hline Middle & 1 & 22.5 & 17 & 34.7 & 4 & 36.4 & 7 & 38.9 & \\
\hline \multicolumn{10}{|c|}{ Father Employment Status } \\
\hline Working & 8 & 100.0 & 48 & 98.0 & 10 & 90.9 & 18 & 100.0 & \multirow{2}{*}{0.051} \\
\hline Not & 0 & 0.0 & 1 & 2.0 & 1 & 9.1 & 0 & 0.0 & \\
\hline \multicolumn{10}{|c|}{ Mother Employment Status } \\
\hline Working & 6 & 75.0 & 25 & 51.0 & 4 & 36.4 & 10 & 55.6 & \multirow{2}{*}{0.425} \\
\hline Not & 2 & 25.0 & 24 & 49.0 & 7 & 63.6 & 8 & 44.4 & \\
\hline \multicolumn{10}{|c|}{ Family Expenditure Level } \\
\hline Upper & 3 & 37.5 & 32 & 69.6 & 5 & 45.5 & 12 & 66.7 & \multirow{2}{*}{0.737} \\
\hline Lower & 5 & 62.5 & 17 & 30.4 & 6 & 54.5 & 6 & 33.3 & \\
\hline Total & 8 & 100.0 & 49 & 100.0 & 11 & 100.0 & 18 & 100.0 & \\
\hline
\end{tabular}

Normal nutrition status is higher than malnutrition status in working status than not on both parents, even the percentage of normal nutrition status almost similar in mother. While, undernutrition status is higher on working status 
on both father and mother, but overnutrition is different. The percentage is higher on father who are working and mother who aren't working, even the percentage in mother almost similar (table 4).

Normal nutrition status is higher in family who have upper expenditure level than lower. Conversely, undernutrition is higher in lower expenditure level and overnutrition is higher in upper expenditure level.

Based on normality test, the data distribution isn't normal $(p=0,000)$ so that the correlation test using the wilcoxon test. The Correlation test showed no significant relationship between socio-economic indexs such as father's education level $(p=0.647)$, mother's education level ( $p=0.051)$, father's employment status $(p=0.425)$, mother's employment status ( $\mathrm{p}=0.737)$, and family expenditure level $(\mathrm{p}=0.943)$ to nutritional status of children based on BAZ indicator.

\section{Discussion}

\subsection{The Relationship between Parents Education Level and Nutritional Status}

In this study, normal nutritional status is higher on parents with upper education even the result isn't significant. The is also in accordance with Tuasuun's et al study [12]. Parents with higher education attainment can improve the children nutrition status because they more alert, having high knowledge, and using democratic parenting pattern [13]. On the other hand, this parenting pattern also gives freedom to their children to eat food, but with good supervision [14].

Overnutrition also higher in parents with higher education. Theis also in accordance with Tuasuun's et al study [12]. Conversely, study in Pekanbaru City showed overnutrition is higher in parents with low education [15]. Parents' education level, especially mothers, is not always followed by high knowledge about children nutrition. As the result, children malnutrition can be greater in parents who have upper education [16]. Because of that, higher education attainment alone is not enough to shape the nutritional status of children. Good parental knowledge and behavior regarding children's nutrition are also important factors. The statement above can also answer why the relationship test isn't significant.

Undernutrition rates in this study is higher in parents with higher education. However, study in North Minahasa, Indonesia shows the opposite because undernutrition rates higher in parent with lower education [7]. Tuasuun's et al study [12] revealed no significant difference between parents with high and low education with undernutrition incidence. Parents with low education tend to have unhealthy lifestyles such as consuming more fast food or lack of physical activity. This habit will affect the nutritional status of children in the future [17].

\subsection{The Relationship between Parents Employment Status and Nutritional Status}

In this study, normal nutritional status is higher in working parents, both fathers and mothers. However, the percentage is almost similar between working and non-working mothers. The results (focusing on mothers) are also in accordance with study in Minahasa [12]. On the other hand, study in North Minahasa shows the opposite [18]. Working parents have higher chance to fulfill family needs because family income can increase. In addition, working parents can also gain additional insights from their peers about family parenting [9].

Undernutrition in this study is higher in working parents. The same results were also obtained in Study in Jakarta [19]. On the other hand, research conducted by Tuasuun's et al study [12] shows the opposite. Working mother or parents who have a high workload can have a negative impact on children's lives in the future, one of them is limitation of main meals at home so that children eat fast food more often. In addition, they also give low attention to their children, especially in fulfilling good nutrition $[4 ; 19]$.

This study shows that overnutrition is higher in working fathers and non-working mothers. However, the percentage is almost similar between working and non-working mothers. Pratasis' et al study [18] show overnutrition is higher in mothers who did not work. On the other hand, Fauzia's et al study [19] shows overnutrition is higher in working parents. Mothers who doesn't work have more time to take care their children so that children are expected to have normal nutritional status [21]. However, Kristo's et al study [22] shows children with parents who did not work reported higher consumption of energy, protein, carbohydrates, and fat. If not controlled properly, then the child can experience excess nutrition.

Based on the Wilcoxon test, there was no significant relationship between parental employment status and children's nutritional status ( $p>0.05)$. The results of this study are also in accordance with Tuasuun's et al study [12]. This is in accordance with several theories and the results of the research above that child of working or non-working parents 
can be malnutrition if the parents don't have sufficient time and adequate knowledge to improve their children's nutritional status.

\subsection{The Relationship between Family Expenditure Level and Nutritional Status}

Normal nutritional status and overnutrition in this study is higher in family who have upper expenditure. While, undernutrition status is higher in lower expenditures level. However, no significant relationship is found between the level of family expenditure on the nutritional status of children in this study $(\mathrm{p}<0.05)$.

Several factors which predispose family spending (including nutrition) are husband income, family income, household needs, and parents' working hours [11]. Therefore, a high level of family income can increase family consumption. However, Assis' study [23] shows family who have welfare problems have a tendency to get less nutritious food in their environment.

This result is also in accordance with the Surabaya City BPS report [6] which states that family expenditure on packaged food is 4-10 times greater than expenditure on staple food in all expenditure groups. This means that family consumption patterns are not only influenced by family spending.

\section{Conclusion}

Both normal nutritional status and malnutrition status in this study is higher in families with good socio-economic status. However, there isn't significant relationship between socio-economic status and nutritional status based on the Wilcoxon test because the lack of data variance. This shows that socio-economic status cannot stand alone in determining the nutritional status of children. Further study are needed with higher population, diverse school, and accurate examination.

\section{Limitations}

Anthropometric results don't valid because it's based on the parent report. The researcher didn't do the examination due to Covid-19 regulation which doesn't permit the reseacher to do the examination directly to the children.

\section{Compliance with ethical standards}

\section{Acknowledgments}

The authors would like to thank to both two schools, SD Al-Irsyad and SD Al Muttaqien who have participated in this study and Faculty of Medicine, Universitas Airlangga, Surabaya, Indonesia for supporting this study.

\section{Disclosure of conflict of interest}

The researcher stated that there isn't conflict of intereset in this study.

\section{Statement of ethical approval}

This research has been ethically approved by the Ethics Committee of the Faculty of Medicine, Universitas Airlangga (KEPK FK Unair) with number No. 100/EC/KEPK/FKUA/2021.

\section{Statement of informed consent}

Participants who enroll in this study have to fill the inform consent by the researcher before fill in the questionnaire.

\section{References}

[1] UNICEF. The State Of The World's Children 2019 growing well in a changing world Children, food and nutrition. New York: UNICEF. 2019.

[2] Utama L, Sembiring A, Sine J. „Perilaku sarapan pagi kaitannya dengan status gizi dan anemia pada anak sekolah dasar". Jurnal Gizi Indonesia. 2018; 7(1): 63-68.

[3] Annisa F. PERBANDINGAN BERAT BADAN SISWA SEKOLAH DASAR NEGERI DAN SWASTA DI JAKARTA SELATAN. Caring: Jurnal Keperawatan. 2021; 10(2): 136-144. 
[4] Aiga H, Abe K, Randriamampionona E, Razafinombana A. Possible causalities between malnutrition and academic performances among primary schoolchildren: a cross-sectional study in rural Madagascar. BMJ Nutrition, Prevention \& Health. 2021; 4(1): 18-29.

[5] Verma S. Prevalence of Malnutrition and its Impact on Academic Performance of School going Children from Rural Area of Rohtak, Haryana. Epidemiology International. 2020; 4(4): 16-19.

[6] Muntaner-Mas A, Palou P, Vidal-Conti J, Esteban-Cornejo I. A Mediation Analysis on the Relationship of Physical Fitness Components, Obesity, and Academic Performance in Children. The Journal of Pediatrics. 2018; 198: 9097.e4.

[7] Wulanta E, Amisi M, Punuh M. HUBUNGAN ANTARA STATUS SOSIAL EKONOMI DENGAN STATUS GIZI PADA ANAK USIA 24-59 BULAN DI DESA KIMA BAJO KECAMATAN WORI KABUPATEN MINAHASA UTARA. JURnal KESMAS. 2019; 8(5): 34-41.

[8] Badan Pusat Statistik (BPS) Kota Surabaya. Statistik Kesejahteraan Rakyat Kota Surabaya 2020". Surabaya: Badan Pusat Statistik. 2020.

[9] Rizky, J dan Santoso B. FAKTOR PENDORONG IBU BEKERJA SEBAGAI K3L UNPAD. Prosiding Penelitian \& Pengabdian Kepada Masyarakat. 2018; 5(2): 158-164.

[10] Akosah-Twumasi P, Emeto T, Lindsay D, Tsey K, Malau-Aduli B. A Systematic Review of Factors That Influence Youths Career Choices - the Role of Culture. Frontiers in Education. 2018; 3: 1-15.

[11] Rosiana W, Saskara I. FAKTOR-FAKTOR YANG MEMPENGARUHI PENGELUARAN RUMAH TANGGA PEKERJA WANITA YANG BEKERJA DI INDUSTRI LAUNDRY RUMAH TANGGA DI KECAMATAN DENPASAR SELATAN. EJurnal Ekonomi dan Bisnis Universitas Udayana. 2018; 2357.

[12] Tuasuun D, Amisi M, Punuh. HUBUNGAN ANTARA STATUS SOSIAL EKONOMI DENGAN STATUS GIZI BALITA USIA 24-59 BULAN DI DESA TATELI III KECAMATAN MANDOLANG KABUPATEN MINAHASA. Jurnal KESMAS. 2019; 8(6): 506-512.

[13] Miyati D, Rasamani U, Fitrianingtyas A. Pengaruh Tingkat Pendidikan Orang Tua Terhadap Pola Asuh Anak. Jurnal Kumara Cendekia. 2021; 9(3): 139-147.

[14] Nasution SZ, Pulungan SW, Siregar CT, Ariga RA, Lufthiani, Amal MRH. Pattern of family care and food consumption of primary school students in medan, Indonesia. 'THE INTERNATIONAL CONFERENCE ON CHEMICAL SCIENCE AND TECHNOLOGY (ICCST - 2020): Chemical Science and Technology Innovation for a Better Future'. 2021.

[15] Wandani Z, Sulistyowati E, Indria D. PENGARUH STATUS PENDIDIKAN, EKONOMI, DAN POLA ASUH ORANG TUA TERHADAP STATUS GIZI ANAK BALITA DI KECAMATAN PUJON KABUPATEN MALANG. Jurnal Kedokteran Komunitas. 2021; 9(1): 1-9.

[16] Numaliza N, Herlina S. Hubungan Pengetahuan dan Pendidikan Ibu terhadap Status Gizi Balita. KESMARS J. Kesehat. Masyarakat, Manaj. dan Adm. Rumah Sakit. 2018; 1: 44-48.

[17] Hemmingsson E. Early Childhood Obesity Risk Factors: Socio-economic Adversity, Family Dysfunction, Offspring Distress, and Junk Food Self-Medication. Curr Obes Rep. 2018; 7: 204-209.

[18] Pratasis N, Malonda N, Kapantow N. HUBUNGAN ANTARA KARAKTERISTIK IBU DENGAN STATUS GIZI PADA BALITA DIDESA ONGKAW KECAMATAN SINONSAYANG KABUPATEN MINAHASA SELATAN. Kesmas. 2018; 7(3). $1-9$.

[19] Fauzia N, Sukmandari N, Triana K. „Hubungan Status Pekerjaan Ibu Dengan Status Gizi Balita“. Journal Center of Research Publication in Midwifery and Nursing. 2019; 3(1): 28-32.

[20] Arage G, Assefa M, Worku T. Socio-demographic and economic factors are associated with nutritional status of adolescent school girls in Lay Guyint Woreda, Northwest Ethiopia. SAGE Open Medicine. 2019; 7.

[21] Pieters, Janneke, Rawlings, Samantha. Parental unemployment and child health in China. Review of Economics of the Household. 2019; 18(1): 207-237.

[22] Kristo AS, Sikalidis AK, Uzun A. Traditional Societal Practices Can Avert Poor Dietary Habits and Reduce Obesity Risk in Preschool Children of Mothers with Low Socio-economic Status and Unemployment. Behav. Sci. 2021; 11(42). 
[23] Assis M, Leite M, Carmo A, Andrade A, Pessoa M, Netto M, Cândido A, Mendes L. Food environment, social deprivation and obesity among students from Brazilian public schools. Public Health Nutrition. 2018; 22(11): 1920-1927.

[24] Badan Pusat Statistik (BPS) Kota Surabaya. Kota Surabaya Dalam Angak". Surabaya: Badan Pusat Statistik. 2021. 